\title{
Hydro Chemical Assessment of Agro-well Water for Irrigation in Thalawa Block
} in Mahaweli System-H in Anuradhapura, Sri Lanka

\author{
N.S. Abeysingha ${ }^{1 *}$, D.S.M.D. Silva ${ }^{1}$ and D.M.S. Duminda ${ }^{1}$ \\ Received: $13^{\text {th }}$ February 2018 / Accepted: $28^{\text {th }}$ May 2018
}

\begin{abstract}
Purpose: Large diameter agro-wells are the most valuable water resources for farmers in Mahaweli system H in Sri Lanka to sustain crop production during the dry spells. Deterioration of water quality is harmful to the crop growth. Present study evaluated the variation of irrigation water quality and water levels of agro-wells in Thalawa irrigation block of Mahaweli system $\mathrm{H}$.
\end{abstract}

Research Method: Water samples from 10 agro-wells were collected during October 2016 to July 2017 once in a month and tested samples for irrigation water quality parameters using standard methods. Water levels were recorded for each sampling date.

Findings: Most of the water quality parameters tested in almost all wells are within the acceptable range for irrigation except for Residual Sodium Carbonate (RSC). $50 \%$ of the wells are safe and rest $50 \%$ of the wells are within marginal range in terms of RSC. Irrigation water quality index (IWQI) was assessed and it varied from 32.6 to 87.7. Considering the mean IWQI (48.2), water of Thalawa block can be characterized as good. The study also revealed that there was sufficient water in wells even during the dry spells and it varied with both the variation of rainfall and canal water availability.

Research Limitations: Sampling was limited to 10 agro-wells for a period of 10 months. This was avoided by selecting representative wells and months covering both dry and wet spells.

Originality/Value: Overall, results envisaged that there is higher potential to use this water for any crop and soil without detrimental to crops grown.

Keywords: Agro-wells, Irrigation Water Quality, Mahaweli System, Water quality index

\section{INTRODUCTION}

The agriculture sector is the largest global water user, and at present $70 \%$ of global freshwater withdrawals and $90 \%$ of global water consumption comprise with agricultural production (Hoekstra and Mekonnen, 2012). Similarly, in Sri Lanka, agriculture sector consumes $80 \%$ of water (Water sector Sri Lanka, 2014). In most tropical lands, groundwater is the important source of the freshwater for drinking and irrigation purposes. Similar to most other countries, groundwater in Sri Lanka in different climatic zones is under serious threat mainly due to pollution occurring through agricultural activities and over extraction that causes a decline of groundwater levels and which resulted in salt water intrusion in the coastal belt (Panabokke and Perera 2005; Chandrajith et al., 2014, Rubasinghe, 2015).

Traditionally, Sri Lanka has been divided into three zones, depending on rainfall: the wet zone in the south west where the annual rainfall is $>2500 \mathrm{~mm}$, the intermediate zone where the annual rainfall is between 1,500 and 2,500 $\mathrm{mm}$, and the dry zone towards the east, north east and south eastern parts where the rainfall is

\footnotetext{
$1^{*}$ Department of Agricultural Engineering and Soil Science, Faculty of Agriculture, Rajarata University of Sri Lanka, Puliyankulama, Anuradhapura, Sri Lanka. nabeysingha@gmail.com ORCID http://orcid.org/0000-0003-4635-3285
} 
below 1,500 mm (Dharmagunewardene, 2003). Water scarcity is experienced predominantly in the dry zone, due to a variety of reasons; unreliability of rainfall, high superficial runoff and evaporative losses, poor storage conditions in hard rock areas, both underground and in surface reservoirs, and increasing pressure of climate change (Ratnayake and Herath, 2005, Villholth and Rajasooriyar, 2010) and human activities. Groundwater is used extensively throughout Sri Lankan context. This is due to the recognition that groundwater provides a relatively stable source of water or acts as a reliable complimentary source to surface water, especially for irrigation, during the dry season or longer dry spells (Villholth and Rajasooriyar, 2010).

Although there was a transfer basin water diversion scheme from the wet zone to dry zone such as Mahaweli water diversion project, and small village reservoirs, the agricultural water demand of the dry zone could not be met. Therefore, an additional and a higher attention was given to explore the possibility of extracting groundwater for cropping during the 1980s and 1990s (Dharmasena, 1989). As a result, at present, large diameter agro-wells are the most valuable water resources for farmers in Mahaweli system H in Sri Lanka (Figure 01) to sustain crop production during the dry spells. In addition, informed exploration methods, improved drilling technology, cheaper pumps available today and government or NGO (NonGovernmental Organization) investment or subsidy schemes have made groundwater a relatively cheap alternative or supplement to surface water (Senarathna, 2002;IGES, 2007). In the central lowlands with shallow regolith aquifers, where significant groundwater extraction for irrigation takes place, the agrowells are typically shallow (4.5-12 m deep) but of large diameter (4-6.5 m) in order to intercept and store sufficient groundwater (IGES, 2007).

Quality of groundwater is equally important as its quantity owing to the suitability of water for various purposes. Variation in groundwater quality in an area is a function of physical and chemical parameters that are greatly influenced by geological formations and anthropogenic activities (Subramani et al., 2005; Schiavo et al., 2006). According to Babiker et al., (2007), the chemistry of groundwater is not only related to the lithology of the area and the residence time of water is in contact with rock material, but also reflects inputs from the atmosphere, from soil and weathering as well as from pollutant sources such as mining, land clearance, saline intrusion, industrial and domestic wastes.

Deterioration of well water quality has been reported in some areas of the dry zone in Sri Lanka (Rubasinghe et al., 2015; Harshan et al., 2016 ). Mahaweli system $\mathrm{H}$ is an area where water diverted from Mahaweli river reaches and this water is mainly allocated for paddy cultivation. Farmers in the area use large diameter agro-wells for the water needs of the other field crops. Thus, it is worth to evaluate the suitability of water of these agro-wells of Mahaweli system $\mathrm{H}$, for irrigation.

\section{MATERIALS AND METHODS}

\section{Study site and selection of Agro-wells}

Agro-well water samples were collected from 10 representative agro-wells in Thalawa block in Mahaweli System H in Sri Lanka. Mahaweli System $\mathrm{H}$ is the first area settled under the Accelerated Mahaweli Development Program; the scheme started in 1975 with the settling of approximately 500 families in the area (Jayewardene and Kilkelly., 1983). System H of Mahaweli is located on the hard rock basement area and these irrigated command areas are serviced by a main, distributary and field canals which cover most of the landscape. However, Agro-well water for irrigation of agricultural crops during the much drier Yala cropping season (April to September) as well as during the water stress times of the Maha cropping season (October to March) is vital to Mahaweli system H (Jayakody, 2006). Figure 01 and 02 show the study site and the spatial distribution of selected Agro-wells for testing the water 
quality. These ten agro wells were selected from Thalawa block representing the canal systems and also spatial distribution of the agro-wells in the area.

\section{Water sample collection and methods of analysis}

This study tested the variation of irrigation water quality parameters and also the water levels of agro wells once in a month during October 2016 to July 2017.

Samples were collected in high density polyethylene bottles of $250 \mathrm{ml}$ capacity. These bottles were pre-cleaned with 1:1 dilute hydrochloric acid and washed with distilled water. Two samples were taken per well for $250 \mathrm{ml}$ sample bottles after rinsing it thrice with the same water and covered with a lid. Water level, $\mathrm{pH}$ and Electrical conductivity (EC) in the agro wells were measured in situ at each sampling date.

Water temperature, $\mathrm{pH}$ and EC were measured immediately using the multi-parameter analyzer (HATCH, Sension 156) that was calibrated prior to analysis. Other parameters such as ammonium nitrogen $\left(\mathrm{NH}^{+}{ }^{-} \mathrm{N}\right)$, nitrate nitrogen $\left(\mathrm{NO}_{3}^{-}-\mathrm{N}\right)$, available $\mathrm{P}$, total $\mathrm{K}, \mathrm{Na}$, $\mathrm{Ca}, \mathrm{Mg}, \mathrm{Fe}, \mathrm{Al}, \mathrm{As}, \mathrm{Cd}$ and $\mathrm{Pb}$ were analyzed in the laboratory by using standard laboratory methods. Calibration of instruments was always carried out before measurements using standard methods. $\mathrm{NH}_{4}^{+}-\mathrm{N}$ content of water samples was determined by UV - visible spectrophotometer with $4500 \mathrm{NH}_{3} \mathrm{~F}$ Phenate method (Solorzano, 1969). $\mathrm{NO}_{3}^{-}-\mathrm{N}$ content of water samples was tested by UV- visible spectrophotometer with salicylic acid method (Cataldo et al., 1975). Available P content of water samples was determined by UV- visible spectrophotometer with ascorbic acid method (Olsen et al., 1954). Total $\mathrm{K}, \mathrm{Na}, \mathrm{Ca}, \mathrm{Mg}, \mathrm{Fe}, \mathrm{Al}, \mathrm{As}, \mathrm{Cd}$ and $\mathrm{Pb}$ contents were measured by ICP-OES following the method Martin et al.,( 1994).

Other than the above-mentioned parameters, Sodium Adsorption Ratio (SAR), Sodium Percentage (SP) and Residual Sodium Carbonate (RSC), Kelly's ratio (KR) and Magnesium hazard $(\mathrm{MH})$ were calculated to test the suitability of water for irrigation.

SAR was calculated from the ratio of sodium to calcium and magnesium (Richards 1954).

$$
S A R=\frac{N a^{+}}{\sqrt{\frac{C a^{2+}+M g^{2+}}{2}}}
$$

All ionic concentrations are expressed in meq/1

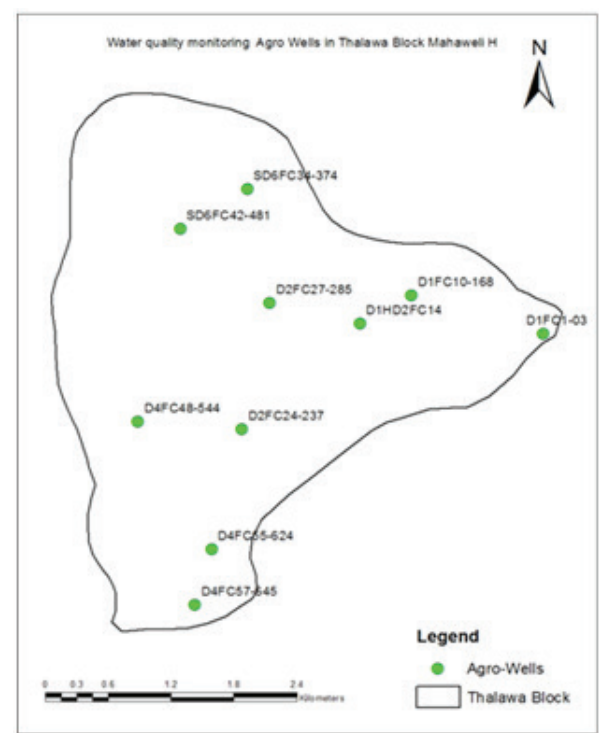

Figure 01: Location of selected Agro-wells in Thalawa block in Mahaweli System H in Sri Lanka 
Sodium percentage ( $\mathrm{Na} \%$ ) was calculated using the following formula,

$N a(\%)=\left(\frac{N a^{+}+K^{+}}{C a^{2+}+M g^{2+}+K^{+}}\right) \times 100$

All ionic concentrations are expressed in meq/1

Residual Sodium Carbonate (RSC) index was calculated from the difference of total carbonate and bicarbonate with total calcium and magnesium (Ragunath 1987).

$\mathrm{RSC}$ index $=\left[\mathrm{HCO}_{3}^{-}+\mathrm{CO}_{3}^{2-}\right]-\left[\mathrm{Ca}^{2+}+\mathrm{MG}^{2+}\right]$

All ionic concentrations are expressed in meq/L

The Kelly's ratio was measured using the expression (Kelly, 1963),

$K R=\frac{N a^{+}}{\mathrm{Ca}^{2+}+M g^{2+}}$

All ionic concentrations are expressed in meq/L

The Magnesium hazard ( $\mathrm{MH})$ was calculated using the equation (Szabolcs and Darab 1964),

$M H=\left(\frac{M g^{+}}{C a^{2+}+M g^{2+}}\right) \times 100$

The impact of irrigation water quality on soil characteristics and crop yield is often a complex phenomenon that involves the combined effect of many parameters. A water quality index provides a single number that expresses overall water quality at a certain location and time based on several water quality parameters. Therefore, in this study we calculated Irrigation Water Quality Index (IWQI) using the following formula (Brindha and Kavitha, 2015; Houatmia et al., 2016) . Irrigation water quality index IWQI

$I W Q I=\Sigma(W n \times Q n)$

$\mathrm{Wn}=$ Unit weight of the nth parameter

Qn $=$ Quality rating or sub index corresponding to the nth parameter

$W=K / \delta$

$\mathrm{K}=$ Proportionality constant which is computed by
$K=1 / \sum_{i=1}^{n} \frac{1}{S_{n}}$

$\sum_{i=1}^{n} \frac{1}{S_{n}}=\frac{1}{S_{p I}}+\frac{1}{S_{E}}+\frac{1}{S_{G}} \ldots . .+\frac{1}{S_{n}}$

$\mathrm{Sn}=$ Standard permissible limit in water for the nth parameter

$\left.Q=100 \times{ }^{[K}-V\right] /[\mathbb{E}-V]$

Where

$\mathrm{Vn}=$ measure value of the nth parameter in ground water at a sampling location

$\mathrm{Vi}=\mathrm{ideal}$ value of the $\mathrm{nth}$ parameter in water $(0$ for all parameters).

\section{RESULTS AND DISCUSSION}

Groundwater needs to be recognized as a critical resource for the future development in agriculture especially under the changing seasonal rainfall pattern in dry zone Sri Lanka. The suitability of groundwater for irrigation depends on its chemical composition. Irrigation water quality is determined in several ways including the degree of acidity or alkalinity $(\mathrm{pH})$, EC, SAR, RSC, Kelly ratio and Magnesium hazard etc. Table 01 shows the results of water quality parameters analyzed for 10 agro-well water averaged over the 10 times sampling and it further shows the mean, minimum, maximum and standard deviation for the block. In this study, we compared the results with FAO irrigation water quality guidelines and FAO irrigation water quality guidelines is shown in Table 02 (Ayers and Westcot, 1994).

\section{Variation of $\mathrm{pH}$}

Acidity or basicity of a solution is determined by its $\mathrm{pH}$. The average $\mathrm{pH}$ of the selected agrowells varied from 6.82 to 7.23 and the average value for the block was 7.03. The optimum $\mathrm{pH}$ range for irrigation water is 6.5 to 8.4 (Table 02, Ayers and Westcot, 1994). Therefore, $\mathrm{pH}$ values are within the safe limit for irrigation. Rubasinghe et al., 2015 observed that the 
average $\mathrm{pH}$ of groundwater of dry zone of Sri to the dilution effect of recharging of agro-well Lanka is 7.22 and the minimum and maximum water with canal water characterized by surface as 5.67 and 8.50 respectively. Lower mean value water source.

recorded in the present study may be attributed

Table 01 : Statistical summary of hydro-chemical parameters tested over agro-wells water

\begin{tabular}{|c|c|c|c|c|c|c|c|c|c|c|c|c|c|c|c|c|c|c|c|}
\hline$\frac{\dot{\dot{z}}}{\overline{\bar{j}}}$ & 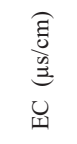 & 茎 & $\begin{array}{l}\stackrel{\widehat{O D}}{\Xi^{m}} \\
\delta^{m}\end{array}$ & 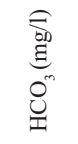 & 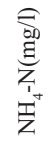 & 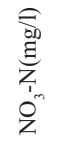 & $\underset{a}{\stackrel{\widehat{\partial D}}{\Xi}}$ & 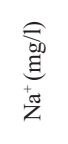 & 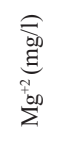 & $\begin{array}{l}\stackrel{\overparen{D D D}}{\Xi} \\
\underset{ \pm}{ \pm}\end{array}$ & 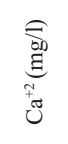 & 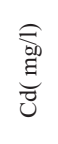 & $\begin{array}{l}\stackrel{0}{00} \\
\stackrel{\Xi}{E} \\
\overrightarrow{2}\end{array}$ & 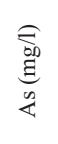 & $\underset{\mathscr{\simeq}}{\mathscr{U}}$ & 总 & के & $\stackrel{\sim}{\underline{v}}$ & $\Xi$ \\
\hline D1FC1-03 & 400.7 & 6.82 & 6.96 & 248.94 & 0.49 & 0.51 & 0.15 & 19.67 & 10.59 & 1.42 & 57.25 & 0 & 1.33 & 0.83 & 1.54 & 0.64 & 21.46 & 0.28 & 27.16 \\
\hline D1FC10-168 & 240.4 & 6.88 & 5.84 & 144.22 & 0.58 & 3.69 & 0.1 & 11.04 & 4.88 & 0.88 & 36.18 & 0.04 & 0.82 & 0.73 & 1.01 & 0.47 & 21.71 & 0.3 & 25.05 \\
\hline D1HD2FC14 & 328.8 & 6.9 & 5.7 & 172.17 & 0.67 & 5.7 & 0.11 & 11.93 & 6.36 & 0.7 & 50.12 & 0 & 1.41 & 0.98 & 1.02 & 0.44 & 21.21 & 0.39 & 24.41 \\
\hline D6FC34-374 & 183.39 & 7.01 & 4.44 & 120.54 & 0.72 & 2.28 & 0.09 & 11.19 & 4.93 & 2.68 & 20.56 & 0 & 0.61 & 0.8 & 0.98 & 0.55 & 25.31 & 0.37 & 30.66 \\
\hline D6FC42-481 & 185.7 & 7.07 & 4.32 & 119.47 & 0.67 & 0.64 & 0.1 & 8.89 & 3.96 & 2.19 & 31.57 & 0 & 0.69 & 0.85 & 0.91 & 0.4 & 17.84 & 0.24 & 20.09 \\
\hline D4FC48-544 & 478 & 6.99 & 7 & 293.71 & 0.7 & 0.94 & 0.47 & 29.15 & 22.69 & 3.18 & 27.87 & 0 & 1.17 & 1 & 2.49 & 1.12 & 36.61 & 0.79 & 50.05 \\
\hline D4FC57-645 & 393.6 & 7.12 & 4.73 & 223.36 & 0.54 & 2.68 & 0.1 & 24.23 & 10.71 & 0.93 & 52.86 & 0 & 1.13 & 1.27 & 1.52 & 0.76 & 23.87 & 0.34 & 30.13 \\
\hline D4FC55-624 & 332.9 & 7.04 & 5.84 & 198.45 & 0.77 & 1.58 & 0.11 & 20.8 & 8.1 & 0.67 & 36.36 & 0.01 & 1.24 & 0.95 & 1.6 & 0.85 & 31.97 & 0.49 & 26.07 \\
\hline D2FC24-237 & 331.3 & 7.23 & 6.18 & 205.15 & 0.41 & 0.95 & 0.1 & 15.48 & 12.89 & 0.59 & 51.93 & 0.18 & 1.87 & 0.9 & 1.29 & 0.5 & 18.15 & 0.23 & 37.08 \\
\hline D2FC27-285 & 232.3 & 7.19 & 6.96 & 138.23 & 0.65 & 0.97 & 0.12 & 12.9 & 6.71 & 3.64 & 38.43 & 0.34 & 0.67 & 0.97 & 1.14 & 0.49 & 20.56 & 0.29 & 32.86 \\
\hline Min & 183.39 & 6.82 & 4.32 & 119.47 & 0.41 & 0.51 & 0.09 & 8.89 & 3.96 & 0.59 & 20.56 & 0 & 0.61 & 0.73 & 0.91 & 0.4 & 17.84 & 0.23 & 20.09 \\
\hline Max & 478 & 7.23 & 7 & 293.71 & 0.77 & 5.7 & 0.47 & 29.15 & 22.69 & 3.64 & 57.25 & 0.34 & 1.87 & 1.27 & 2.49 & 1.12 & 36.61 & 0.79 & 50.05 \\
\hline Mean & 310.71 & 7.03 & 5.8 & 186.42 & 0.62 & 1.99 & 0.15 & 16.53 & 9.18 & 1.69 & 40.31 & 0.06 & 1.09 & 0.93 & 1.35 & 0.62 & 23.87 & 0.37 & 30.36 \\
\hline SD & 93.34 & 0.13 & 0.97 & 55.14 & 0.11 & 1.57 & 0.11 & 6.32 & 5.29 & 1.08 & 11.55 & 0.11 & 0.38 & 0.14 & 0.45 & 0.22 & 5.72 & 0.16 & 7.98 \\
\hline
\end{tabular}

Table 02: Guideline for interpretation of water quality for irrigation adopted from FAO irrigation water quality guidelines

\begin{tabular}{|c|c|c|c|c|}
\hline \multirow{2}{*}{ Potential irrigation problems } & \multicolumn{4}{|c|}{ Degree of Restriction on Use } \\
\hline & Units & None & Slight to moderate & Severe \\
\hline $\begin{array}{l}\text { Salinity (Affects crop water availability) } \\
\mathrm{EC}_{\mathrm{w}}\end{array}$ & $\mathrm{dS} \mathrm{m}^{-1}$ & $<0.7$ & $0.7-3.0$ & $>3.0$ \\
\hline \multicolumn{5}{|c|}{$\begin{array}{l}\text { Infiltration (Affects infiltration rate of water into the soil; } \\
\text { evaluate using } \mathrm{EC}_{\mathrm{w}} \text { and SAR together) }\end{array}$} \\
\hline SAR 0-3 & & $>0.7$ & $0.7-0.2$ & $<0.2$ \\
\hline SAR 3-6 & & $>1.2$ & $1.2-0.3$ & $<0.3$ \\
\hline SAR 6-12 & & $>1.9$ & $1.9-0.5$ & $<0.5$ \\
\hline SAR $12-20$ & & $>2.9$ & $2.9-1.3$ & $<1.3$ \\
\hline SAR $20-40$ & & $>5.0$ & $5.0-2.9$ & $<2.9$ \\
\hline \multicolumn{5}{|l|}{ Specific ion toxicity (Affects sensitive crops) } \\
\hline \multicolumn{5}{|l|}{ Sodium $(\mathrm{Na})$} \\
\hline Surface irrigation & SAR & $<3$ & $3-9$ & $>9$ \\
\hline Sprinkler irrigation & meq $1^{-1}$ & $<3$ & $>3$ & \\
\hline \multicolumn{5}{|l|}{ Miscellaneous effects ( On susceptible crops) } \\
\hline Nitrate $\left(\mathrm{NO}_{3}-\mathrm{N}\right)$ & $\mathrm{mg} \mathrm{l}^{-1}$ & $<5$ & $5-30$ & $>30$ \\
\hline $\begin{array}{l}\text { Bicarbonate }\left(\mathrm{HCO}_{3}^{-}\right) \text {(Overhead sprinkler only) } \\
\mathrm{pH}\end{array}$ & meq $1^{-1}$ & $\begin{array}{l}<1.5 \\
\text { Nor }\end{array}$ & $\begin{array}{c}1.5-8.5 \\
\text { al range } 6.5-8.4\end{array}$ & $>8.5$ \\
\hline
\end{tabular}

$E C_{w}$ Electrical conductivity of water, recorded at $25^{\circ} C$; SAR, Sodium absorption ratio 


\section{Variation of EC, salinity and sodicity hazard}

Electrical Conductivity (EC) denotes the total ionized constitutes of water which is a measure of dissolved salts in water. Average EC of the tested samples varied from 183 to $478 \mu \mathrm{S} / \mathrm{m}$ which are in desirable range and can be used for irrigation without any restriction (Table 02). Dry zone area is generally characterized by high EC due to higher mineralization to groundwater (Rubasinghe et al., 2015). Comparatively lower value $($ mean $=310 \mu \mathrm{S} / \mathrm{m})$ recorded in the present study may be attributed to the recharging of surface water from Mahaweli canal system in the area. Sodium concentration is a vital parameter in classifying irrigation water as it affects the permeability of soil and induces infiltration problem. Sodium hazard is also usually expressed in terms of the sodium adsorption ratio (SAR). Groundwater could be classified based on SAR as excellent (0-10), good (10-18), doubtful (18-26) and unsuitable $(>26)$ (Richards, 1954). According to the present analysis, SAR of agro well water of Mahaweli $H$ area varied from 0.44 to 1.12 and therefore, the water is excellent for irrigation in terms of SAR. According to FAO guidelines, SAR $<3$ (Table 02) has no any restriction to use even for sprinkler irrigation. Therefore, the Agro-well waters in Thalawa block has no any restriction to use as an irrigation source for any crops in terms of SAR. Plotting the data on the US salinity diagram of irrigation water quality (Figure 02) shows that water samples are low sodium hazard and low to medium salinity hazard. It indicates that agro-well water can be used for irrigation on almost all types of soil. Moreover, Sodium percentage (SP) calculated for groundwater in each agro-wells was plotted against conductance in Wilcox diagram (Wilcox, 1948) (Figure 03) and shows that almost all groundwater samples are excellent and good for irrigation. The Kelly ratio is also used to determine the hazardous effect of sodium on water for irrigation use. In this study region, it varied from 0.23 to 0.79 with an average of 0.37 (Table 01). Kelly ratio $>1$ is considered to be unsuitable for irrigation as they can turn the excess level of $\mathrm{Na}^{+}$. Therefore, agro-well water at Thalawa block is within the safe limit in terms of Kelly ratio.

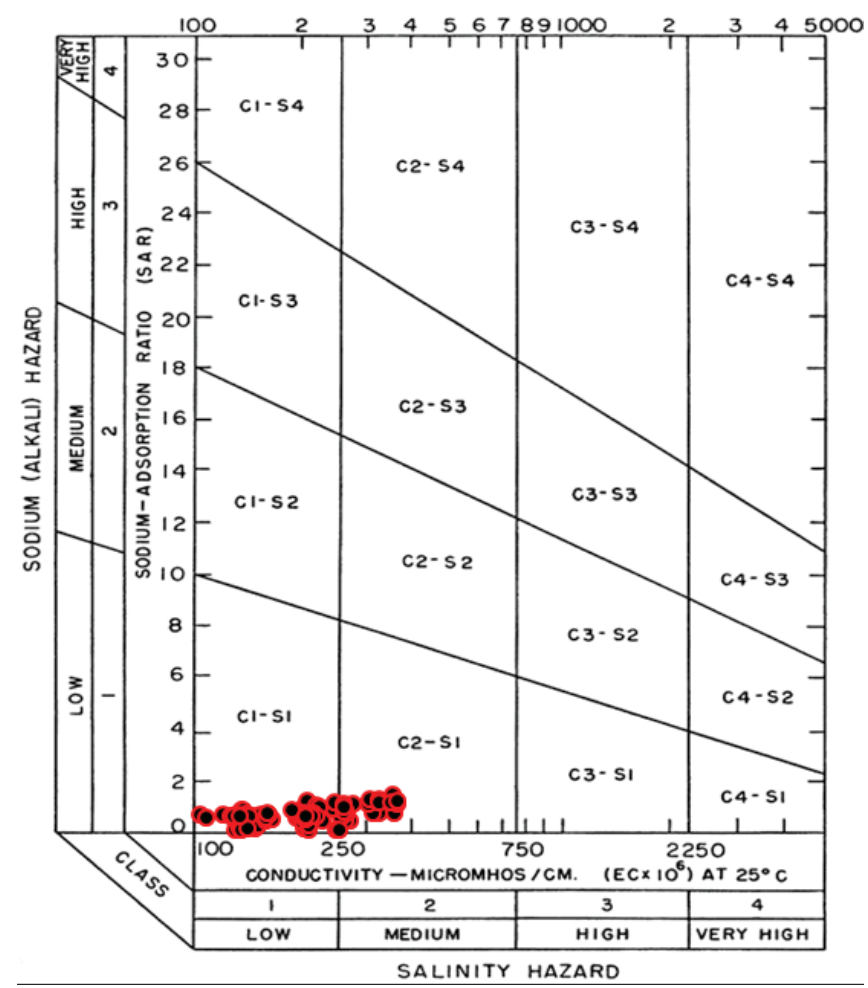

Note: Sodium hazard (SAR), S1: Low, S2: Medium, S3: High, S4: Very high; Salinity hazard: C1: Low, C2: Medium, C3: High, C4: Very high

Figure 02: $\quad$ Rating of GW samples in relation to salinity and sodium hazard 


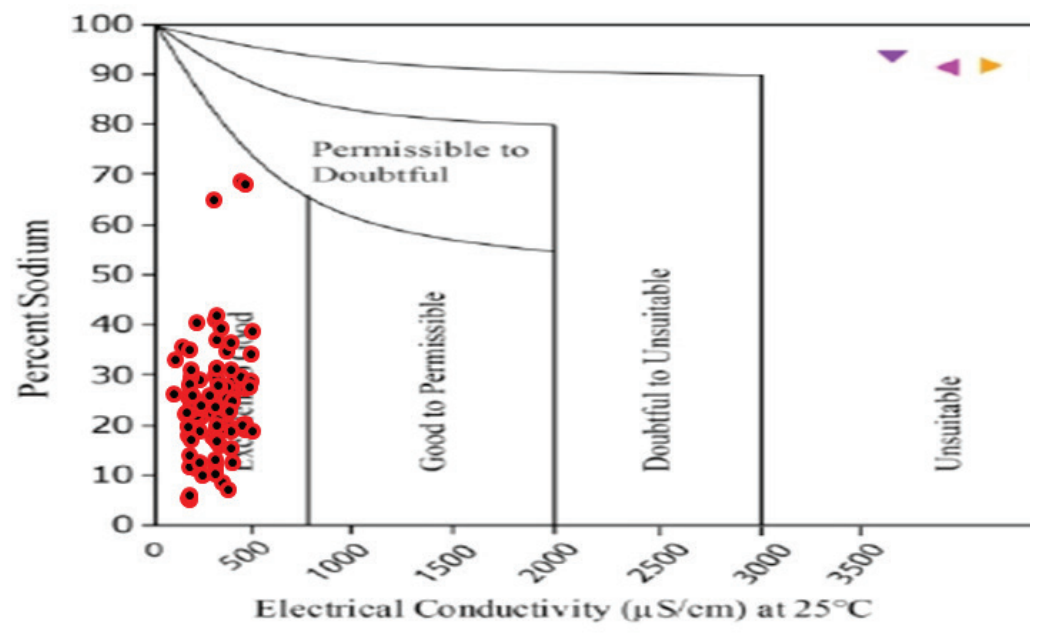

Figure 03: Rating of GW samples on the basis of electrical conductivity and percent sodium (after Wilcox 1948)

The RSC indicated the excess of carbonates and bicarbonates over calcium and magnesium in irrigation water. The data presented in Table 01 revealed that RSC values of irrigation water varied from 0.91 to $2.49 \mathrm{meq} / \mathrm{l}$. RSC less than $1.25 \mathrm{meq} / 1$ are considered safe and waters with RSC of $1.25-2.50 \mathrm{meq} / \mathrm{L}$ are within the marginal range. If it is $>2.5$ considered as unsuitable (Eaton, 1950; Sutharsiny et al., 2012). According to this classification, $50 \%$ of the wells are safe and rest $50 \%$ of the wells are within marginal range. Moreover, variation of $\mathrm{HCO}_{3}$ and $\mathrm{CO}_{3}{ }^{2-}$ are shown in Table 01. According to Carrow et al., 2008, $\mathrm{HCO}_{3}^{-}$values can range widely, but as a general guideline, bicarbonate $>120 \mathrm{mg} / \mathrm{l}$ and $\mathrm{CO}_{3}{ }^{2-}>15 \mathrm{mg} / 1$ start to become concern, especially when sodium concentration are $>$ $100 \mathrm{mg} / \mathrm{L}$ (Carrow et al., 2008). Though the study period, average $\mathrm{HCO}_{3}^{-}$of agro well water are $>120 \mathrm{mg} / \mathrm{L}, \mathrm{CO}_{3}{ }^{2-}$ and $\mathrm{Na}^{+}$concentration are less than the 15 and $100 \mathrm{mg} / 1$ respectively. Therefore, there is a very less potential to form sodic soil if this water is used continuously for irrigation.

\section{Variation of nutrient parameters}

Nitrogen (NH4-N and NO3-N), Phosphorus and Potassium are major plant nutrients and these nutrients present in water can be beneficial for irrigation but need to be accounted for in the overall fertilization program of crops. However, these nutrients accumulations showed the eutrophication of the wells specially, wells which are not lined and excessive presence of some nutrient parameter may also be harmful to specific crops.

$\mathrm{NO}_{3}-\mathrm{N}$ concentration of agro wells ranged from 0.51 to $5.7 \mathrm{mg} / \mathrm{l}$ and $\mathrm{NH}_{4}-\mathrm{N}$ varied from 0.41 to $0.77 \mathrm{mg} / \mathrm{l}$ (Table 1 ). According to FAO guidelines, sensitive crops may be affected by nitrogen $\left(\mathrm{NO}_{3}-\mathrm{N}\right)$ concentrations above 5 $\mathrm{mg} / \mathrm{l}$. Therefore, waters of well D1HD2FC14, D1FC10-168 having higher $\mathrm{NO}_{3}^{-}$level may become concern when cultivating $\mathrm{N}$ sensitive crop. Phosphorus concentrations should be as low as possible (lower than $1.0 \mathrm{mg} / \mathrm{L}$ ) to avoid causing algal blooms. As per the average results of agro well water, water is good in quality that may not show considerable eutrophication in terms of P. However, continuous monitoring may require specially unlined wells in the area because maximum $\mathrm{P}$ concentration (1.78) recoded in well D4FC48-544 can be caused to eutrophication which may ultimately result in lowering the water holding capacity of these large diameter agro-wells.

Farmers who cultivate in this area use micro irrigation techniques for irrigation. One important problem of micro irrigation is clogging 
of drippers, sprinklers and tube walls. Potential clogging agents are physical suspended solid (sand, silt, clay and organic matter), chemical precipitation (calcium or magnesium carbonate, heavy metal hydroxides or oxides or carbonate and fertilizer) and biological (algae and bacteria) agents (Ayers and Westcot, 1985). The recorded high levels of nutrients in these agro wells result in excess algae and bacteria growth that may ultimately lead to clogging problems in micro irrigation systems.

\section{Variation of heavy metals}

This study also tested the concentration of few heavy metals as the people in the area suffer from chronic kidney disease of unknown etiology (CKDu) (Jayathilake et al., 2013; Jayasumana et al., 2013). Heavy metals specially $\mathrm{Cd}$ and As are said to be causative factors for $\mathrm{CKDu}$. Therefore, waters of wells were tested for heavy metals. However, the results show that the heavy metals are in minute quantities and are below the WHO standard (Table 1). FAO has recommended maximum $\mathrm{Cd}$, $\mathrm{As}$ and $\mathrm{Pb}$ level in irrigation water for long term use as $0.01,0.1$ and $5 \mathrm{mg} / \mathrm{l}$ (Ayres and Westcot, 1976), hence the water of these wells are well suitable for irrigation.

\section{Irrigation water quality index}

Irrigation Water Quality Index (IWQI) based on the six indices: $\mathrm{MH}, \mathrm{RSC}, \mathrm{Na} \%$, SAR, was calculated from equations 6 and 7. Ideal value of the nth parameter in water represented by ' $\mathrm{Vi}$ ' in Eq. 10 was considered as ' 0 ' for all indices. The weightage assigned to these indices are given in Table 3, and the classification of the groundwater samples based on IWQI is given in table 4. Average IWQI for agro-well water varied between 32.6 and 87.77 with a mean of 48.17. IWQI value varied temporally in different agro wells and minimum and maximum values for each agro-wells and their suitability based on the mean IWQI for irrigation is shown in Table 4. Water of 6 agro-wells can be classified as good and 3 well waters are poor and one is very poor according to the classification by Brindha and Kavitha (2015). Considering the average value for the Thalawa block (48.17), water of this block can be classified as good.

Table 03: Weight of each parameter and the suitable limit for irrigation

\begin{tabular}{ccccc}
\hline Parameter & Unit & Suitable limit for irrigation & Unit weight & Reference \\
\hline MH & No unit & 50.0 & 0.040 & Szabolcs and Darab (1964) \\
RSC & Meq/l & 2.5 & 0.811 & Eaton ( 1950) \\
Na \% & $\%$ & 60 & 0.033 & Wilcox ( 1955) \\
SAR & No unit & 18 & 0.112 & Richard ( 1954) \\
EC & $\mu \mathrm{s} / \mathrm{cm}$ & 2250.0 & 0.0009 & Freeze and Cherry ( 1979) \\
\hline
\end{tabular}

Table 04: IWQI of different Agro-wells and their suitability for irrigation

\begin{tabular}{lcccc}
\hline Well No. & Average IWQI & Max IWQI & Min IWQI & Suitability \\
\hline WELL N0 - D1FC1-03 & 53.88 & 126.80 & 2.31 & Poor \\
WELL N0 - D1FC10-168 & 36.37 & 67.20 & 1.70 & Good \\
WELL N0 - D1HD2FC14 & 36.60 & 84.17 & 1.55 & Good \\
WELL N0 - SD6FC34-374 & 36.21 & 80.00 & 2.99 & Good \\
WELL N0 - SD6FC42-481 & 32.60 & 59.65 & 0.69 & Good \\
WELL N0 - D4FC48-544 & 87.77 & 164.51 & 5.44 & Very poor \\
WELL N0 - D4FC57-645 & 53.77 & 133.51 & 2.26 & Poor \\
WELL N0 - D4FC55-624 & 56.61 & 110.27 & 3.27 & Poor \\
WELL N0 - D2FC24-237 & 46.24 & 110.98 & 2.39 & Good \\
WELL N0 - D2FC27-285 & 41.61 & 101.44 & 2.40 & Good \\
Average for the area & 48.17 & 164.51 & 0.69 & Good \\
\hline
\end{tabular}

(IWQI 0-25: Excellent, 26 -50: Good, 51-75: Poor, 76-100: very poor, > $100:$ Unsuitable, adopted from Brindha and Kavitha 2015) 
Relationship among irrigation water quality Parameters

This study also tested the relationship among water quality parameters and also with depth to water level of agro-wells, using spearman's rho correlation coefficient (Table 5). The correlation analysis showed that depth to water table has a weak positive correlation with $\mathrm{pH}, \mathrm{Na}^{+}, \mathrm{Mg}^{2+}$, $\mathrm{K}^{+}, \mathrm{Ca}^{2+}$, As, and SAR. As well as depth to water table has a week negative correlation with $\mathrm{HCO}_{3}{ }^{-}$ , $\mathrm{NO}_{3}^{-}, \mathrm{PO}_{4}{ }^{3-}$ and $\mathrm{RSC}$ (Table 5). EC and $\mathrm{pH}$ were not highly correlated with any investigated major ions. But, EC showed weekly positive correlation with $\mathrm{CO}_{3}{ }^{2-}, \mathrm{HCO}_{3}^{-}, \mathrm{PO}_{4}{ }^{2-}, \mathrm{Na}^{+}, \mathrm{Mg}^{2+}$, $\mathrm{Ca}^{2+}(\mathrm{r}=0.3,0.54,0.33,0.38,0.32$ and 0.24$)$ and approximate similar correlation was observed by Houatmia et al., (2016). pH showed weekly positive correlation with $\mathrm{Mg}^{2+}$ and $\mathrm{K}^{+}(\mathrm{r}=0.21$, 0.21 ) and negatively correlated with $\mathrm{CO}_{3}^{2-}$, $\mathrm{HCO}_{3}^{-}, \mathrm{PO}_{4}^{2-}(\mathrm{r}=-0.52,-0.35,-0.46)$ than other investigated ions (Table 5). The concentration of these ions in groundwater depends on the mineral dissolution and solubility, ion exchange, evaporation, anthropogenic activities, following the topographical features and water flow-path condition (Houatmia et al., 2016). $\mathrm{Na}^{+}$showed highly positive correlation with $\mathrm{Mg}^{2+}, \mathrm{Ca}^{2+}$ and $\mathrm{K}^{+}(\mathrm{r}=0.94,0.89$ and 0.69$)$ and $\mathrm{Pb}$ ions showed a strongly positive correlation with $\mathrm{Na}^{+}, \mathrm{Mg}^{2+}$, $\mathrm{Ca}^{2+}(\mathrm{r}=0.74,0.68$ and 0.81$)$ which may indicate the influence of evaporation and agricultural activities.

\section{Variation of Water level}

Auto water level meter was used to measure the depth to water in each well during 10 month period and depth variation is shown in Figure 04. Further Figure 04 shows the total rainfall during the last 30 days before each sampling date. Shallow water table (more ground water potential) was observed in D4FC48-544 well whereas the deepest water level was recorded in D4FC57-645.

The graph shows that during October 2016, June and July 2017 rainfall has not been recorded but, the water table depth has not that much higher compared to the other dates. Only the month January showed that water level has increased (depth to water table has decreased) in almost all wells with the rainfall. Therefore, this graph infer that variation of water levels of these wells are associated both with the variation of rainfall and water availability of the Mahaweli canal system. In addition, we analyzed the relationships between the number of days water allocated for canals system and water depth of wells and also water depth at the sampling date with total rainfall of previous 15 days using simple liner regression (Figure 05).

Table 05: Correlation matrix of the hydro-chemical parameters

\begin{tabular}{|c|c|c|c|c|c|c|c|c|c|c|c|c|c|c|c|c|c|c|}
\hline & DWT & $\mathrm{EC}$ & $\mathrm{pH}$ & $\mathrm{CO}_{3}^{2-}$ & $\mathrm{HCO}_{3}^{-}$ & $\mathrm{NH}_{4}^{+}$ & $\mathrm{NO}_{3}^{2-}$ & $\mathrm{PO}_{4}^{2-}$ & $\mathrm{Na}^{+}$ & $\mathrm{Mg}^{2+}$ & $\mathrm{K}^{+}$ & $\mathrm{Ca}^{2+}$ & $\mathrm{Cd}$ & $\mathrm{Pb}$ & As & $\mathrm{RSC}$ & SAR & SP \\
\hline DWL & 1.000 & & & & & & & & & & & & & & & & & \\
\hline EC & 0.01 & 1.00 & & & & & & & & & & & & & & & & \\
\hline $\mathrm{pH}$ & $0.19^{*}$ & -0.14 & 1.00 & & & & & & & & & & & & & & & \\
\hline $\mathrm{CO}_{3}{ }^{2-}$ & -0.17 & $0.30^{* *}$ & $-0.52^{* *}$ & 1.00 & & & & & & & & & & & & & & \\
\hline $\mathrm{HCO}_{3}^{-}$ & $-0.20^{\circ}$ & $0.54^{* *}$ & $-0.35^{* *}$ & $0.65^{* *}$ & 1.00 & & & & & & & & & & & & & \\
\hline $\mathrm{NH}_{4}^{+}-\mathrm{N}$ & -0.02 & -0.05 & -0.10 & 0.18 & $0.29^{* *}$ & 1.00 & & & & & & & & & & & & \\
\hline $\mathrm{NO}_{3}^{2-}-\mathrm{N}$ & $-0.37^{* *}$ & -0.08 & -0.14 & 0.03 & -0.01 & $0.34^{* *}$ & 1.00 & & & & & & & & & & & \\
\hline $\mathrm{PO}_{4}{ }_{4}^{2-} \mathrm{P}$ & $-0.29^{* *}$ & $0.33^{* *}$ & $-0.46^{* *}$ & $0.67^{* *}$ & $0.54^{* *}$ & 0.07 & 0.09 & 1.00 & & & & & & & & & & \\
\hline $\mathrm{Na}^{+}$ & $0.34^{* *}$ & $0.38^{* *}$ & 0.12 & -0.00 & -0.02 & $-0.33^{* * *}$ & $-0.33^{* * *}$ & -0.19 & 100 & & & & & & & & & \\
\hline $\mathrm{Mg}^{2+}$ & $0.29^{* *}$ & $0.32^{* *}$ & $0.21^{*}$ & -0.08 & -0.05 & $-0.25^{*}$ & $-0.29^{* * *}$ & $-0.32^{* *}$ & $0.94^{* * *}$ & 1.00 & & & & & & & & \\
\hline $\mathrm{K}^{+}$ & $0.27^{* * *}$ & -0.06 & $0.21^{*}$ & -0.14 & $-0.22^{*}$ & -0.12 & $-0.27^{* *}$ & $-0.28^{* *}$ & $0.69^{* * *}$ & $0.72^{* *}$ & 1.00 & & & & & & & \\
\hline $\mathrm{Ca}^{2+}$ & $0.32^{* *}$ & $0.24^{*}$ & 0.01 & 0.08 & -0.05 & $-0.35^{* *}$ & $-0.31^{* *}$ & $-0.22^{*}$ & $0.89^{* *}$ & $0.86^{* *}$ & $0.59^{* *}$ & 1.00 & & & & & & \\
\hline $\mathrm{Cd}$ & 0.16 & 0.02 & 0.04 & 0.09 & 0.13 & 0.00 & -0.17 & 0.04 & 0.05 & 0.03 & -0.034 & 0.04 & 1.00 & & & & & \\
\hline $\mathrm{Pb}$ & 0.11 & $0.19^{*}$ & -0.02 & 0.09 & -0.15 & $-0.54^{* *}$ & $-0.21^{*}$ & -0.01 & $0.74^{* *}$ & $0.68^{* *}$ & $0.46^{* \circ}$ & $0.81^{* *}$ & -0.09 & 1.00 & & & & \\
\hline As & $0.24^{*}$ & 0.02 & $0.35^{* *}$ & $-0.49^{* *}$ & $-0.46^{* *}$ & -0.11 & -0.18 & $-0.30^{* *}$ & 0.15 & 0.14 & 0.18 & 0.01 & 0.07 & -0.04 & 1.00 & & & \\
\hline RSC & $-0.45^{* *}$ & $0.22^{*}$ & $-0.35^{* *}$ & $0.50^{* *}$ & $0.63^{* *}$ & $0.20^{*}$ & $0.29^{* *}$ & $0.64^{* *}$ & $-0.48^{* *}$ & $-0.52^{* *}$ & $-0.47^{* * *}$ & $-0.49^{* *}$ & -0.09 & $-0.25^{*}$ & $-0.48^{* *}$ & 1.00 & & \\
\hline SAR & $.033^{* *}$ & $0.48^{* *}$ & 0.02 & $0.24^{*}$ & $0.35^{* *}$ & 0.19 & $-0.27^{* * *}$ & 0.15 & $0.49^{* *}$ & $0.36^{* *}$ & $0.28^{* *}$ & $0.25^{*}$ & 0.18 & 0.02 & $0.21^{*}$ & -0.12 & 1.00 & \\
\hline SP & -0.02 & 0.17 & -0.06 & 0.13 & $0.25^{*}$ & $0.29^{* *}$ & -0.05 & $0.21^{*}$ & -0.11 & $-0.24^{*}$ & -0.11 & $-0.36^{* *}$ & 0.09 & $-0.39^{* *}$ & 0.13 & $0.27^{* *}$ & $0.54^{* *}$ & 1.00 \\
\hline
\end{tabular}

*. Correlation is significant at the 0.05 level, **. Correlation is significant at the 0.01 level; DWT-Depth to water table (m) 


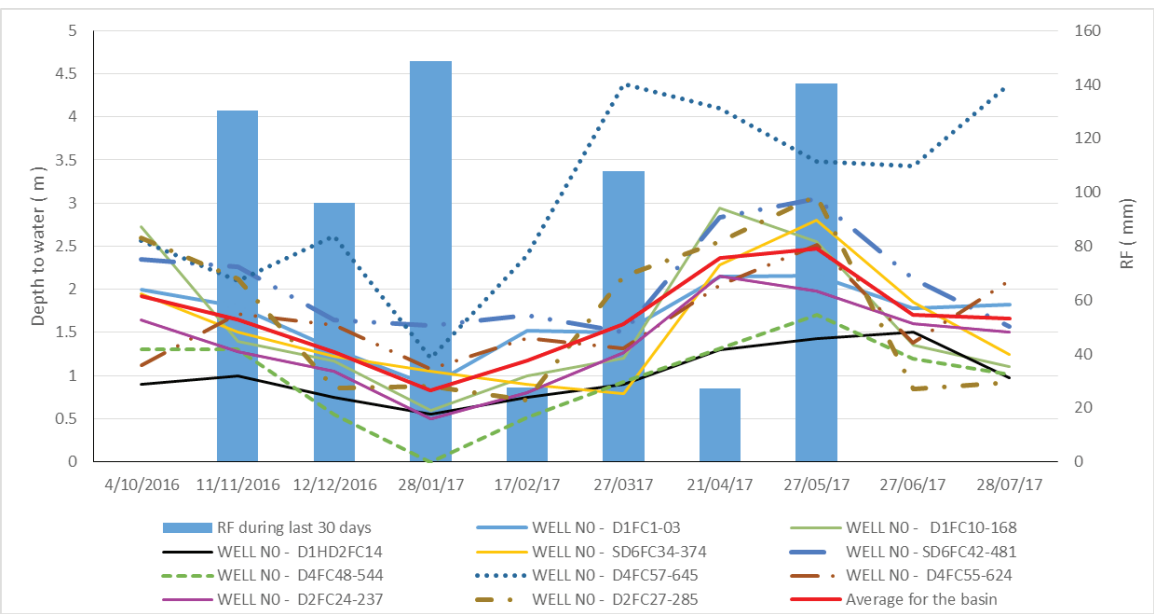

Figure 04: Temporal variation of water level in different wells and rainfall of the Thalawa block during October 2016 to July 2017.
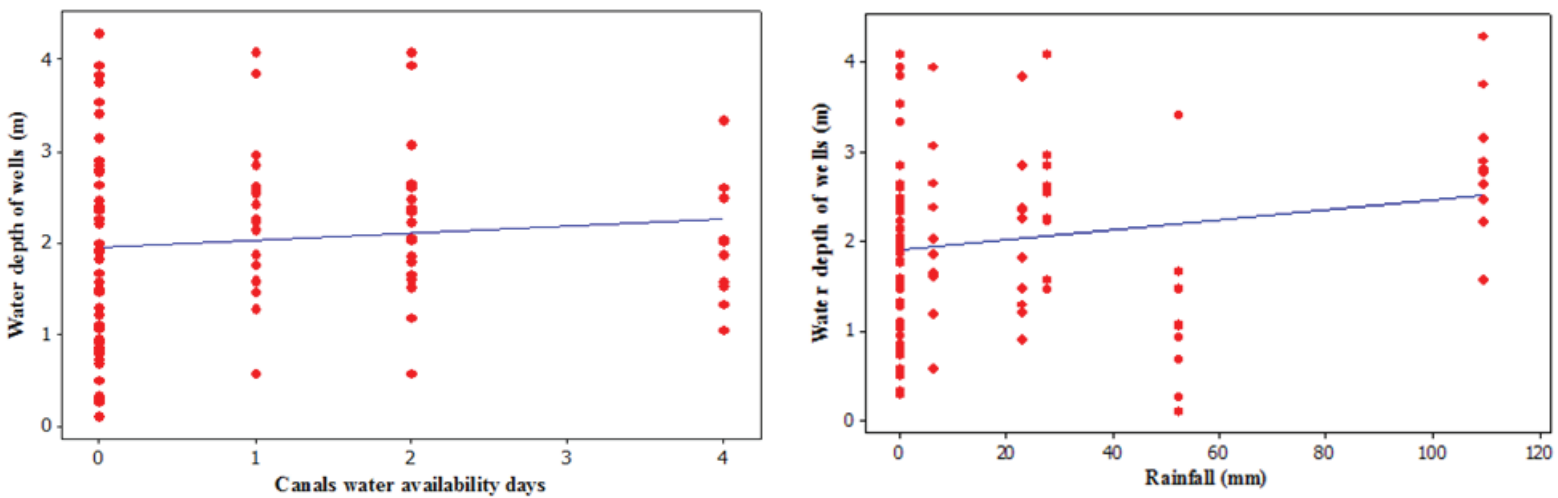

Figure 05: Variation of depth of water of agro-wells with the canal water availability days and rainfall of the area.

These analysis showed that water depth (WD) increases with rainfall $(\mathrm{WD}=0.9025+0.0056$ $\mathrm{RF}\left(\mathrm{R}^{2}=0.04\right)$ and also canal water availability days $\left(\mathrm{WD}=1.8549+0.0851\right.$ DAYS $\left(\mathrm{R}^{2}=0.037\right)$. Villholth and Rajasooriya (2010) pointed out that in the dry zone hard rock areas where tank cascade system and Mahaweli water diversions dominate shallow surface and groundwater interactions are evident. This study is also an evidence to the surface and groundwater interactions of Mahaweli water diversion areas.

\section{CONCLUSIONS}

Water in almost all agro-wells in thalawa block was of good quality for irrigation for any crops in terms of $\mathrm{pH}, \mathrm{EC}, \mathrm{SAR}, \mathrm{SP}$, heavy metals and nutrient parameters. According to $\mathrm{HCO}_{3}$ concentration, $50 \%$ of the wells are safe and rest $50 \%$ of the wells are within marginal range. But, there is a very little possibility to generate sodic soils if these waters are used continuously for irrigation as the SP is quite low. However, considering the combined effect of few water quality parameters using IWQI, three wells can be classified poor to very poor in quality for irrigation. In none of the wells water studied cannot be classified as unsuitable as per the IWQI. It can be concluded that there is higher potential to use agro well water in Thalawa block for any crops with very little danger of increasing problem to the soils and growing crops. This study also showed that there is ample water available in agro-wells for further cultivation even during dry spells and the water level of wells vary both with the rainfall and canal water availability. 


\section{Data availability statement}

The datasets generated during and/or analysed during the current study are available from the corresponding author on reasonable request.

\section{ACKNOWLEDGMENTS}

We wish to thank to the International Water Management Institute for the financial support given to carry out the study.

\section{REFERENCES}

Ayers, R.S. and Westcot, D.W. (1994). FAO Irrigation and Drainage paper, 29 Rev. 1, Reprinted 1989, 1994, ISBN 92-5-102263-1, Food and Agriculture Organization of the United Nations Rome, 1985. DOI: http://dx.doi.org/10.18356/241c79d2-en

Ayres, R.S. and Westcot, D.W. (1976). Water Quality for Agriculture. Irrigation and Drainage Paper 29. Food and Agriculture Organization of the United Nations. Rome. DOI: http:// dx.doi.org/10.1093/ww/9780199540884.013.u33867

Ayers, R.S. and Westcot, D.W. (1985). Water Quality for Agriculture, FAO Irrigation and Drainage Paper 29 rev 1. FAO, UN, Rome. pp. 174. DOI: http://dx.doi.org/10.1002/9781119080176. app5

Babiker, I.S., Mohamed, M.A.A. and Hiyama, T. (2007). Assessing groundwater quality using GIS, Water Resources Management. 21 : 699 -715. DOI: http://dx.doi.org/10.1007/s11269006-9059-6

Brindha, K. and Kavitha, R. (2015). Hydrochemical assessment of surface water and groundwater quality along Uyyakondan channel, south India, Environmental Earth Science. 73:53835393. DOI: http://dx.doi.org/10.1007/s12665-014-3793-5

Carrow, R.N., Duncan, R.R. and Huck, M.T. (2008). Turfgrass and Landscape Irrigation Water Quality: Assessment and Management, CRC press, Tayler and Francis Group. DOI: http:// dx.doi.org/10.1201/9781420081947

Cataldo, D.A., Maroon, M.Schrader,L.E. and Youngs, V.L.(1975). Rapid colorimetric determination of nitrate in plant tissues by nitration of salicylic acid, Communication in Soil Science and Plant Analysis. 6(1): 71-80. DOI: http://dx.doi.org/10.1080/00103627509366547

Chandrajith, R.., Chaturangani, D., Abeykoon, S. Barth, J.A.C., van Geldern R., Edirisinghe E.A.N.V. and Dissanayake, C.B. (2014). Quantification of groundwater-seawater interaction in a coastal sandy aquifer system: a study from Panama, Sri Lanka. Environmental Earth Science. 72(3): 867-877. DOI: http://dx.doi.org/10.1007/s12665-013-3010-y

Dharmagunewardene, H.A. (2003). Groundwater quality problems in Sri Lanka, National Workshop on Fresh Water Related Issues, JNU, New Delhi. March 31-April 2, 2003. DOI: http://dx.doi.org/10.2166/wst.2003.0661

Dharmasena, P.B. (1989). Optimum utilization of the storage in village tanks: Tropical Agriculturist .145: 1-9. DOI: http://dx.doi.org/10.5353/th_b3198682

Eaton, F.M. (1950). Significance of carbonates in irrigation waters. Soil Science. 69: 123-133. DOI: http://dx.doi.org/10.1097/00010694-195002000-00004

Freeze, R.A. and Cherry, J.A. (1979) Groundwater. Prentice Hall Inc, New Jersey. DOI: http:// dx.doi.org/10.3138/cmlr.35.4.746 
Harshan, S., Thushyanthy, M., Gunatilake J., Srivaratharasan, T. and Gunaalan, K. (2016). Assessment of water quality index of ground water quality in Chunnakam and Jaffna Town, Sri Lanka, Ving. Journal of Science. 13( 1-2) : 84-91. DOI: http://dx.doi.org/10.4038/ vingnanam.v13i1-2.4126

Houatmia, F., Azouzi, R., Cheref, A. and Bédir, M. (2016). Assessment of groundwater quality for irrigation and drinking purposes and identification of hydrogeochemical mechanisms evolution in Northeastern, Tunisia, Environmental Earth Sciences. 75 (9) : 1-7. DOI: http:// dx.doi.org/10.1007/s12665-016-5441-8

Hoekstra, A.Y. and Mekonnen, M.M. (2012). The water footprint of humanity, Proceedings of National academy of science USA. 109(9): 3232-3237. DOI: http://dx.doi.org/10.1073/ pnas. 1109936109

I.G.E.S. (2007). Sustainable groundwater management in Asian cities. A final report of research on sustainable water management policy. Institute for Global Environmental Strategies, Japan, ISBN 4-88788-039-9. DOI: http://dx.doi.org/10.1007/978-4-431-78399-2_9

Jayakody, A.N. (2006). Large diameter shallow agro-wells - a national asset or a burden for the nation? The Journal of Agricultural Sciences. 2(1): 1-10. DOI: http://dx.doi.org/10.4038/jas. v2i1.8108

Jayatilake, N., Mendis, S., Maheepala, P. and Mehta, F.R. (2013). Chronic kidney disease of uncertain etiology: prevalence and causative factors in a developing country. $B M C$ Nephrology. 14: 180-193. DOI: http://dx.doi.org/10.1186/1471-2369-14-180

Jayasumana, M.A.C.S., Paranagama, P.A., Amarasinghe, M.D., Wijewardane, K.M.R.C. ,Dahanayake, K.S., Fonseka, S.I. et al. (2013). Possible link of Chronic arsenic toxicity with Chronic Kidney Disease of unknown etiology in Sri Lanka., Journal of Natural Sciences Research. 3(1): 64-73. DOI: http://dx.doi.org/10.4038/mljsl.v3i1.7316

Jayewardene, J. and Kilkelly, M.K. (1983). System H of the Mahaweli development project, Sri Lanka. diagnostic analysis, Water Management Synthesis Report No. 20, Water Management Synthesis Project University Services Center Colorado State University Fort Collins, Colorado in cooperation with the Consortium for International Development October 1983. DOI: http://dx.doi.org/10.2172/10116120

Kelly, W.P. (1963). Use of saline irrigation water, soil science. 95(4): 355-39. DOI: http://dx.doi. org/10.1097/00010694-196306000-00003

Kumar, S.K., Chandrasekar, N., Seralathan, P., Godson, P.S. and Magesh, N.S. (2011). Hydrogeochemical study of shallow carbonate aquifers, Rameswaram Island, India. Environmental Monitoring and Assessment. DOI: http://dx.doi.org/10.1007/s10661-0112249-6

Martin, T.D., Brockhoff, C.A. and Creed, J.T. (1994). EMMC Methods Work Group - Method 200.7, Revision 4.4, U.S. Environmental Protection Agency, Cincinnati, OH. DOI: http:// dx.doi.org/10.2172/10180273

Olsen, S.R., Cole, C.V., Watanabe, F.S. and Dean, L.A. (1954). Estimation of available phosphorus in soil by extraction with sodium bicarbonate. USDA Cir.No.939. DOI: http://dx.doi. org/10.1097/00010694-196005000-00010 
Panabokke, C.R. and Perera, A.P.G.R.L. (2005). Groundwater Resources of Sri Lanka. Report, Water Resources Board 2A, Gregory’s Avenue, Colombo-7, Sri Lanka. DOI: http://dx.doi. org $/ 10.5337 / 2014.201$

Ragunath, H. M. (1987). Groundwater, Wiley Eastern Ltd., New Delhi.563. DOI: http://dx.doi. org/10.1080/00908319208956248

Rathnayake, U.R. and Herath, G.B.B. (2005). Recent changes in water cycle and its effect on natural disasters and ecosystem of Sri Lanka, In Proceedings of preparatory workshop on Sri Lankan national water development report-for UN-WWAP, Wattala, Sri Lanka. DOI: http:// dx.doi.org/10.4038/sljda.v5i0.7124

Richards, L.A. (1954). Diagnosis and improvement of saline and Alkali soils. USDA handbook 60. DOI: http://dx.doi.org/10.1097/00010694-195408000-00012

Rubasinghe, R., Gunatilake, S.K. and Chandrajith, R. (2015). Geochemical characteristics of groundwater in different climatic zones of Sri Lanka, Environmental Earth Science. 74: 3067-3076. DOI: http://dx.doi.org/10.1007/s12665-015-4339-1

Schiavo, M.A., Havser, S., Gusimano, G. and Gatto, L. (2006). Geochemical characterization of groundwater and submarine discharge in the south-eastern Sicily. Continental Shelf Research. 26(7): 826-834. DOI: http://dx.doi.org/10.1016/j.csr.2005.12.001

Senarathna, A. (2002). Groundwater exploration in Sri Lanka, personal experience. In Proceedings of Sympoisum, Peradeniya in Sri Lanka, September 30, 2002, 'use of groundwater in Agriculture in Sri Lanka, Agricultural Engineering Society of Sri Lanka, Peradeniya, pp.6673. DOI: http://dx.doi.org/10.1093/ww/9780199540884.013.u164634

Solorzano, L. (1969). Determination of ammonia in natural waters by the phenol hypochlorite method, Limnology and Oceanography. 14: 799-801. DOI: http://dx.doi.org/10.4319/ 10.1969.14.5.0799

Sutharsiny, A., Pathmarajah, S., Thushyanthy, M. and Meththika,V. (2012). Characterization of Irrigation Water Quality of Chunnakam Aquifer in Jaffna Peninsula, Tropical Agricultural Research. 23(3): 237 - 248. DOI: http://dx.doi.org/10.4038/tar.v23i3.4661

Subramani, T., Elango, L. and Damodarasamy, S.R. (2005). Groundwater quality and its suitability for drinking and agricultural use in Chithar River Basin, Tamil Nadu, India, Environmental Geology. 47: 1099-1110. DOI: http://dx.doi.org/10.1007/s00254-005-1243-0

Szabolcs, I. and Darab, C. (1964). The influence of irrigation water of high sodium carbonate content of soils, Proceedings of 8th ISSS, Trans, v.2, pp.802-812. DOI: http://dx.doi. org/10.1007/978-94-011-9422-8_5

Villholth, K.G. and Rajasooriyar, L.D. (2010). Groundwater Resources and Management Challenges in Sri Lanka-an Overview, Water Resources Management. 24: 1489-1513. DOI: http://dx.doi.org/10.1007/s11269-009-9510-6

Wilcox, L.V. (1955). Classification and use of irrigation waters. U.S. Department of Agriculture Circular 969, Department of Agriculture, Washington. DOI: http://dx.doi.org/10.5962/bhl. title. 16960 
The Journal of Agricultural Sciences - Sri Lanka, 2018, Vol.13, No. 3

Wilcox, L.V. (1948). The quality of water for irrigation use. US Department of Agriculture, Tech Bull 962, Washington, DC, pp.1-40. DOI: http://dx.doi.org/10.2172/1021847 